\title{
Arsenic abrogates the estrogen-signaling pathway in the rat uterus
}

\author{
Aniruddha Chatterjee and Urmi Chatterji*
}

\begin{abstract}
Background: Arsenic, a major pollutant of water as well as soil, is a known endocrine disruptor, and shows adverse effects on the female reproductive physiology. However, the exact molecular events leading to reproductive dysfunctions as a result of arsenic exposure are yet to be ascertained. This report evaluates the effect and mode of action of chronic oral arsenic exposure on the uterine physiology of mature female albino rats.

Methods: The effect of chronic oral exposure to arsenic at the dose of $4 \mathrm{microg} / \mathrm{ml}$ for 28 days was evaluated on adult female albino rats. Hematoxylin-eosin double staining method evaluated the changes in the histological architecture of the uterus. Circulating levels of gonadotropins and estradiol were assayed by enzyme-linked immunosorbent assay. Expression of the estrogen receptor and estrogen-induced genes was studied at the mRNA level by RT-PCR and at the protein level by immunohistochemistry and western blot analysis.

Results: Sodium arsenite treatment decreased circulating levels of estradiol in a dose and time-dependent manner, along with decrease in the levels of both LH and FSH. Histological evaluation revealed degeneration of luminal epithelial cells and endometrial glands in response to arsenic treatment, along with reduction in thickness of the longitudinal muscle layer. Concomitantly, downregulation of estrogen receptor (ER alpha), the estrogen-responsive gene - vascular endothelial growth factor (VEGF), and G1 cell cycle proteins, cyclin D1 and CDK4, was also observed.

Conclusion: Together, the results indicate that arsenic disrupted the circulating levels of gonadotropins and estradiol, led to degeneration of luminal epithelial, stromal and myometrial cells of the rat uterus and downregulated the downstream components of the estrogen signaling pathway. Since development and functional maintenance of the uterus is under the influence of estradiol, arsenic-induced structural degeneration may be attributed to the reduction in circulating estradiol levels. Downregulation of the estrogen receptor and estrogen-responsive genes in response to arsenic indicates a mechanism of suppression of female reproductive functions by an environmental toxicant that is contra-mechanistic to that of estrogen.
\end{abstract}

\section{Background}

Arsenic is a naturally occurring metalloid with potent toxic and mutagenic effects [1]. It is present ubiquitously in the environment and is released from both natural and man-made sources [2]. Arsenic in drinking water is one of the topmost environmental threats worldwide, based on the potential exposure of people to arsenic and the numerous diseases with which it has been associated [36]. In Southeast Asian countries like India, Bangladesh and Taiwan, millions of people are threatened by arsenic poisoning, leading to several diseases and disorders, and

* Correspondence: urmichatterji@gmail.com

1 Department of Zoology, University of Calcutta, 35 Ballygunge Circular Road, Kolkata-700019, India

Full list of author information is available at the end of the article even death [7]. The problem of arsenic poisoning is not only restricted to developing countries but developed nations like USA, Germany, China, Japan and Australia are also plagued by problems of arsenic contamination $[8,9]$. Interestingly, inorganic arsenic is found to be more potent than the organic form and trivalent compounds are found to be more toxic than pentavalent ones [10].

Chronic intake of arsenic is strongly associated with an increased risk of skin, lung, liver and other cancers, type 2 diabetes, cardiovascular diseases, neurological and cognitive defects, and reproductive and developmental problems [11-16]. According to World Health Organization, the permissible limit of arsenic in drinking water is 0.01 $\mathrm{mg} / \mathrm{l}$, which is equivalent to $10 \mathrm{ppb}[9,15,17,18]$. Recently, however, it has been reported that there is an increased 
risk of arsenic toxicity, even at the low and permissible dose of $10 \mathrm{ppb}$ [9,15-17]. However, a large population all over the world is exposed to far higher levels of arsenic [19-23]. In certain areas in the Indian subcontinent, the maximum arsenic concentration in ground water was found to be around $3700 \mathrm{ppb}$ [24] to $4700 \mathrm{ppb}$ [18], leading to several physiological damages to human beings. Although arsenic is not a direct acting xenotoxin or mutagen, it may increase DNA damage or mutations indirectly by altering DNA repair, thus acting as a co-carcinogen or promoter of tumor growth [25].

Till date, there is very little information regarding the mechanism of arsenic action on the ovarian steroidogenic function and the female reproductive axis, particularly in wide areas of India and other countries, where the levels occurring in drinking water exceed the admissible limits of $10 \mathrm{ppb}$ [20-22,24]. It is, however, known that women who are exposed to this level of arsenic often suffer from spontaneous abortion and stillbirth [26], and maternal exposure to arsenic also affects the health of newborn and promotes carcinoma incidences in them [27-29]. Although it has been hypothesized that the reproductive hazards may be due to disruption of the steroid hormone signaling pathway [30,31], the actual target of arsenic is probably a part of the mechanism which is used to regulate gene expression and not just the receptor itself [31]. The estrogen receptor (ER) is the most divergent of all steroid hormone receptors and may undergo divergent co-regulatory interactions and unique activation/de-activation steps. Previous studies have suggested that arsenic can interfere with ER functioning, although the exact mechanism remains to be ascertained [31]. Since arsenic acts as a potent environmental estrogen [32], it was explicable to study the arsenic-stimulated estrogen receptor signaling pathway, expression of estrogen responsive genes such as VEGF, and G1 cell cycle regulatory proteins CDK4 and cyclin D1, since these molecules are known to be primary responsive factors to estrogen administration in the rat uterine endometrium [33-35]. Thus, the objective of this study was to elucidate the role of arsenic as an endocrine disruptor and determine the molecular mechanism underlying arsenic action in the rat uterus.

\section{Methods}

Animals

Female Sprague-Dawley rats, aged 15-16 weeks and weighing 100-120 g, were collected from the breeding colony and maintained under controlled conditions $(25 \pm$ $2^{\circ} \mathrm{C}$ temp, $50 \pm 15 \% \mathrm{RH}$ and normal photoperiod $12 \mathrm{~h}$ dark and $12 \mathrm{~h}$ light) through out the experiment. The animals were given sterile food pellets and water ad libitum and allowed to acclimatize to the laboratory environment for 5 days prior to the commencement of the experiments. The Principles of Laboratory Animal Care (NIH
Publication No 85-23, revised in 1985) as well as specific Indian Laws of Animal Protection (ILAP) were followed through out the experimental schedule.

\section{Drug treatments, selection of optimum dose and time and study of estrous cycle}

Sodium arsenite (E-Merck, Germany) was used for study. All other chemicals were procured from Sigma Aldrich (USA). The rats were divided randomly into different groups, each containing 5 animals. Group I (control group) animals were fed 10-12 ml pure distilled water/ animal/day, while other groups were fed the same volume of water containing sodium arsenite at different concentrations $(0.4 \mu \mathrm{g} / \mathrm{ml}, 4 \mu \mathrm{g} / \mathrm{ml}, 40 \mu \mathrm{g} / \mathrm{ml}$ and $80 \mu \mathrm{g} / \mathrm{ml})$ [2729,36-38] and maintained for different time periods (7 days, 14 days, 28 days and 56 days) in order to determine the optimum dose and time of arsenic action. The optimum time and dose of arsenic action, as determined by circulating estradiol concentrations, were selected for all subsequent experiments. The dose of arsenic thus selected conforms to environmentally relevant concentrations. Vaginal smears were collected every morning from all of the animals before fresh treatment of arsenic. The smears were double stained with eosin-hematoxylin and examined microscopically.

\section{Tissue and blood collection}

Animals were anesthetized by intraperitoneal injection of sodium barbital. Uteri were quickly removed from the experimental animals and washed in $0.9 \%(\mathrm{w} / \mathrm{v})$ cold normal saline, pat dried and weighed in an electrical monopan balance (Lutron GM-300 P). Small representative tissue slices were processed for histological and immunohistochemical studies, RNA isolation and protein purification. Blood was collected from the heart and serum was isolated for ELISA.

\section{Assay of serum estradiol, LH and FSH}

ELISA (DRG International ELISA Kit) was performed for estimating the circulating levels of estradiol, $\mathrm{LH}$ and FSH. For assay of serum estradiol, $25 \mu \mathrm{l}$ each of standard, control and treated serum samples were added to respective wells coated with anti-estradiol antibody and incubated with $200 \mu \mathrm{l}$ of enzyme conjugate for 2 hours at room temperature. Subsequently, $100 \mu \mathrm{l}$ of substrate was added and incubated for 15 minutes at room temperature. Reactions were stopped using $50 \mu \mathrm{l}$ of stop solution and the O.D. was measured at $450 \mathrm{~nm}$. Each sample was run in triplicate [39]. For assay of serum FSH and LH, $25 \mu \mathrm{l}$ of standard, control or treated serum samples were added to respective wells coated with anti-FSH and anti-LH antibodies and incubated with $100 \mu \mathrm{l}$ of enzyme conjugate for 30 minutes at room temperature. Wells were washed with aqua dest and $100 \mu \mathrm{l}$ of substrate was added to each well. After incubation for 10 minutes at room temperature, 
reactions were stopped using $50 \mu \mathrm{l}$ of stop solution and the O.D. measured at $450 \mathrm{~nm}[38,39]$. The intra-assay and inter-assay variations were found to be less than $9 \%$ and $10 \%$, respectively. Limit of detection for estradiol was 3.6 $\mathrm{pg} / \mathrm{ml}$, for $\mathrm{LH}$ was $0.45 \mathrm{mIU} / \mathrm{ml}$ and for FSH was 0.28 $\mathrm{mIU} / \mathrm{ml}$.

\section{Histology and morphometric analysis}

Uterine slices (selected randomly from the proximal, middle and distal regions of the uterus) from control and treated animals were fixed in bouins fluid. Graded dehydration of the tissue was done by 70 to $100 \%$ alcohol in subsequent steps and xylene was used as the clearing agent. For histological studies, $5 \mu$ paraffin sections were stained by standard hematoxylin-eosin double staining procedure and observed under a microscope [31]. The stained sections were subjected to morphometric analysis using the eye piece scale (occulometer) and the stage micrometer. The stage and the eye piece scales were adjusted until there was a parallel point between the two scales. The number of the eye piece divisions and its corresponding stage measurements was noted. The occulometer fixed into the microscope was then focused through stained sections of the tissue to allow for measurement of the luminal diameter, height of luminal epithelial cells, size of endometrial glands and longitudinal muscle layer [40].

\section{Immunohistochemistry}

Immunohistochemistry was performed according to a previously established protocol [26]. Briefly, sections were deparaffinized, hydrated, boiled in $0.1 \mathrm{M}$ sodium citrate buffer ( $\mathrm{pH}$ 6.0) for 10 minutes and treated with $3 \%$ (v/v) $\mathrm{H}_{2} \mathrm{O}_{2}$ in PBS (30 min) to block endogenous peroxidase activity. Non-specific staining was blocked by incubating the sections with bovine serum at room temperature. Sections were subsequently incubated with rabbit anti-ER IgG (sc-542, Santa Cruz Biotech, CA, 1:500) for 18 hours at $4^{\circ} \mathrm{C}$ and then with goat anti-rabbit HRP-conjugated secondary antibody (1:1000) for 1 hour at room temperature. Peroxidase was visualized using 3,3'-diaminobenzidine. The sections were counterstained with hematoxylin. Slides that served as negative controls were not incubated with the primary antibody [27].

\section{RNA extraction and semi-quantitative RT-PCR}

Uterine tissues were collected from the arsenic-treated and untreated rats. $100 \mathrm{mg}$ of tissue samples were frozen quickly in liquid nitrogen and total RNA was isolated using TRI reagent (SIGMA), dissolved in DEPC water and quantified by UV spectrophotometry. The RNA samples were subjected to DNase treatment prior to RT-PCR. Reverse transcription reaction was performed at $42^{\circ} \mathrm{C}$ with $5 \mu \mathrm{g}$ of RNA in $5 \times$ reaction buffer (Fermentas, USA) containing 100 pmol random hexamer primer, $10 \mathrm{mM}$ dNTP mixture (Fermentas, USA), 20 units of RNase inhibitor (Bioline, USA) and 200 units of RevertAid ${ }^{\mathrm{m}} \mathrm{M}$ MuLV Reverse Transcriptase (Fermentas, USA). PCR was initiated using $2.5 \mu \mathrm{g}$ cDNA, $10 \mathrm{mM}$ dNTPs and 1 unit of Taq DNA Polymerase (Vivantis, USA). PCR amplifications were performed using the primers listed in Table 1[41-45]. PCR was carried out for 40 cycles using an annealing temperature of $58^{\circ} \mathrm{C}$ for $\mathrm{ER} \alpha$ and $55^{\circ} \mathrm{C}$ for VEGF, CDK4 and cyclin D1. Samples were fractioned by $2 \%$ agarose gel electrophoresis and quantified using a BioRad Gel Documentation System.

\section{Western blot analysis}

Tissue samples were lysed in ice-cold RIPA Buffer (150 $\mathrm{mM} \mathrm{NaCl}, 50 \mathrm{~mm}$ Tris, $0.1 \%$ Triton X-100 and $0.1 \%$ SDS containing protease inhibitors [4-(-2-aminoethyl benzenesulphonyl fluoride), EDTA, leupeptin, aprotinin and bestatin, SIGMA]. The concentration of total protein was determined by Bradford assay and equal amount of proteins $(30 \mu \mathrm{g})$ were fractioned by $8 \%$ SDS-PAGE. Proteins were electrically transferred to PVDF membranes and blocked for 2 hours at room temperature with $5 \%$ non-fat dry milk. Blots were subsequently incubated with ER $\alpha$, VEGF and CDK4 antibodies raised in rabbit and cyclin D1 antibody raised in mouse (1:1000), for 18 hours at $4{ }^{\circ} \mathrm{C}$. Anti- $\beta$ tubulin was used as a loading control. Blots were subsequently incubated with HRP-conjugated goat antirabbit and goat anti-mouse IgG secondary antibodies (1:2000), respectively, for 1 hour at $25^{\circ} \mathrm{C}$. Immunoreactive proteins were detected by staining the membranes with 3,3'-diaminobenzidine in $50 \mathrm{mM}$ Tris ( $\mathrm{pH}-7)$ containing $0.2 \% \mathrm{H}_{2} \mathrm{O}_{2}$ [46] and bands were quantified by a BioRad Gel Documentation System.

Table 1: Sequences of the oligonucleotides used for semi-quantitative RT-PCR

\begin{tabular}{lcccc}
\hline Gene & Forward primer & Reverse primer & Ref. \\
\hline ER a & GGAGACATGAGAGCTGCCAAC & & \\
VEGF & GATCAAGTTCATGGACGTCT & CCAGCAGCATGTCGAAGATC & [41] \\
Cyclin D1 & CTGGCCATGAACTACCTGGA & GATCAAGTCATGGACGTCT & [43] \\
GAPDH & GACATCAAGGTGGTGAAGCAG & GTCACACTTGATCACTCTGG & [45] \\
CDK4 & TGGTGTCGGTGCCTATGGGA & CACCCTGTGCTGTAGCCATATTC & [42] \\
\hline
\end{tabular}




\section{Statistical analysis}

Results of the experiments performed in triplicates were expressed as mean and standard error of mean of different groups, using a statistical software package (Graphpad). The differences between the mean values were evaluated by one-way ANOVA followed by multiple Students' t-tests. P-values less than 0.05 were considered statistically significant $[47,48]$. Densitometric analysis of the RT-PCR and western blot results were carried out using NIH Scion Image analysis to assess the fold-change in arsenic-treated rats as compared to the control animals.

\section{Results}

\section{Effect of arsenic on food consumption, body weight and} estrous cycle

It was observed that during the entire duration of the experiment, water intake and food consumption of the control and treated rats remained unchanged. In addition, the body weights of the treated animals were not significantly different from that of the control ones. However, after 28 days of arsenic treatment, a significant decrease in the wet weight of uterus was observed in comparison to the control group (Table 2). In addition, in the control group, regular estrous cycles of 4-5 days were noted whereas, in the arsenite-treated group, a constant diestrous phase was observed after $22 \pm 2$ days of arsenic treatment.

\section{Dose and time-dependent effect of arsenic on serum estradiol levels}

In order to determine the effect of arsenic on serum estradiol levels in female Sprague-Dawley rats, the optimum dose responsible for the changes and the minimum time required to initiate maximum changes were resolved by ELISA of serum estradiol. Rats were treated with different doses of sodium arsenite and monitored at the end of 28 days. As depicted in Figure 1a, the serum estradiol levels reduced at a dose of $0.4 \mu \mathrm{g} / \mathrm{ml}$ and decreased by 4fold in rats fed with arsenic-containing water at a dose of $4 \mu \mathrm{g} / \mathrm{ml}$, as compared to control rats $(\mathrm{p}<0.05)$. The level did not decrease further when the rats were fed arsenic-

Table 2: Body weight and uterine wet weight in response to

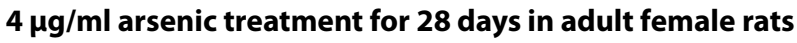

\begin{tabular}{ccc}
\hline Treatment & Body weight (in gm) & $\begin{array}{c}\text { Uterine wet } \\
\text { weight (in } \mathbf{~ m g})\end{array}$ \\
\hline Control & $132 \pm 1.67$ & $146 \pm 2.31$ \\
$4 \mu \mathrm{g} / \mathrm{ml} \mathrm{NaAsO}$ & $131.6 \pm 1.32$ & $104.3 \pm 1.94^{* *}$ \\
\hline
\end{tabular}

Individual weights of control and arsenic-treated rats were attained at the end of the experimental schedule. Each value represents mean $\pm S E, n=5$. (ANOVA followed by multiple Students' t-tests, ${ }^{* *} p<0.01$, as compared with respective control). a

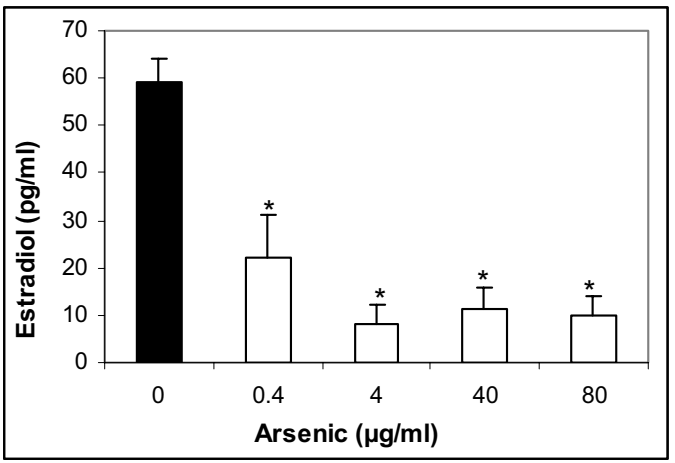

b

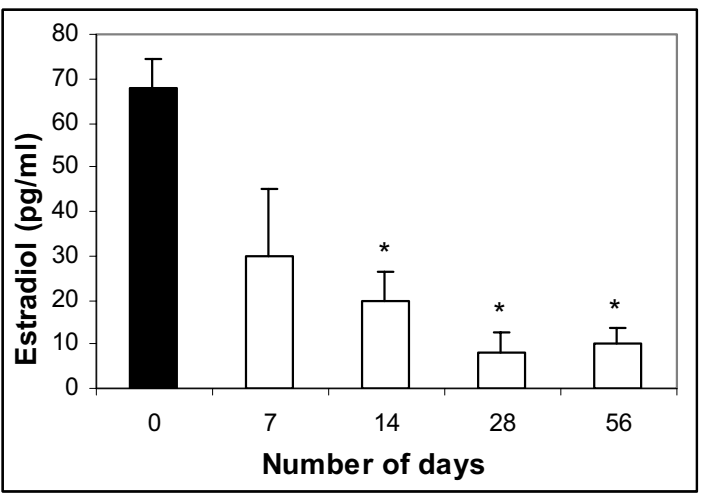

Figure 1 Serum estradiol levels of untreated and arsenic treated female Sprague Dawley rats. Rats were exposed to different doses of sodium meta-arsenite for different time periods, as mentioned in the Methods section. (a) Arsenic has a dose-dependent inhibitory effect on circulating estradiol levels. The dose at which maximum reduction is observed is $4 \mu \mathrm{g} / \mathrm{ml}$, beyond which the level does not change significantly. Each value represented as mean $\pm S E, n=3, p<0.05$. (b) The minimum time period required to initiate the maximum decrease in estradiol levels is 28 days. No further reduction is observed even when rats were exposed to arsenic for 56 days. Each value represented as mean $\pm S E, n=3, p<0.05$.

containing water at the dose of $40 \mu \mathrm{g} / \mathrm{ml}$ and $80 \mu \mathrm{g} / \mathrm{ml}$. The minimum time required for maximum effect of arsenic was resolved to be 28 days, beyond which continuous treatment did not affect the serum estradiol levels up to a period of 56 days (Figure 1b). Hence, all subsequent experiments were performed with the optimum effective dose and time of $4 \mu \mathrm{g} / \mathrm{ml}$ (equivalent to $4 \mathrm{ppm}$ ) and 28 days, respectively.

\section{Effect of arsenic on serum concentration of $\mathrm{LH}$ and FSH}

$\mathrm{LH}$ and FSH are gonadotropins which are upstream components of estradiol signaling, and are required for the 
development and quantitative maintenance of normal reproductive cycle in pubertal rats. It was observed that chronic exposure of rats to $4 \mu \mathrm{g} / \mathrm{ml}$ sodium arsenite for 28 days significantly decreased the serum LH and FSH concentrations (Figure 2), as detected by ELISA. Synthesis and secretion of estradiol is under the control of these gonadotropins, hence rendering them important components of sex steroid regulation. Thus, the reduction of $\mathrm{LH}$ and FSH may therefore be responsible for the consequent reduction in estradiol levels, as seen above.

\section{Arsenic-induced histological changes of the uterus}

Histological analysis of $4 \mu \mathrm{g} / \mathrm{ml}$ arsenic-treated rats showed significant alterations in the uterine morphology as compared to the untreated rats. Occulometric studies revealed rats that were exposed to arsenic showed a decrease in (i) the size and invaginations of the uterine luminal diameter, (ii) height of luminal epithelial cells, (iii) number and organization of endometrial glands, and (iv) the width of the myometrium (Table 3). The compact, tall, columnar epithelial cells lining the highly invaginated lumen of the untreated uterus (Figure 3a) were well defined as compared to the treated uterus (Figure $3 b$ ), with rounded nuclei located on a prominent basement membrane (Figure 3c). However, the height and organization of the epithelial cells were affected with arsenic treatment and revealed distortion of the cells with irregularshaped nuclei, along with disappearance of a distinct basement membrane (Figure 3d). Additionally, the number and size of endometrial glands in the endometrial stroma were well defined in the control uterus (Figure 3e) and were significantly reduced in the treated animals (Figure 3f). Reduction in the thickness of the longitudinal

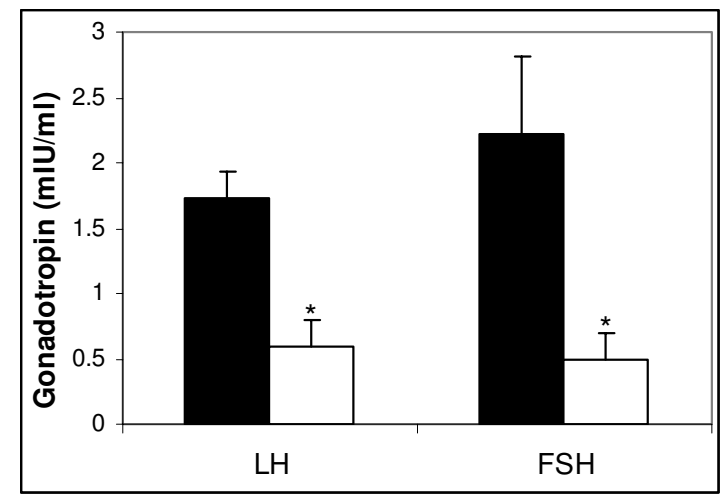

Figure 2 Serum gonadotropin levels of untreated and arsenictreated female rats. Sprague-Dawley rats were treated with $4 \mu \mathrm{g} / \mathrm{ml}$ sodium meta-arsenite for 28 days, as described in the Methods section. The results indicate that arsenic has an inhibitory effect on serum levels of both LH and FSH (white bars), as compared to the control animals (black bars). Each value represented as mean $\pm S E, n=3, p<0.05$. muscles comprising the myometrium, as compared to the untreated uterus (Figure $3 \mathrm{~g}$ ), was also observed in the uterus of rats exposed to arsenic (Figure $3 \mathrm{~h}$ ).

\section{Effect of arsenic on estrogen receptor expression}

Immunohistochemical localization of estrogen receptors were detected by staining for the ER $\alpha$ proteins in the uteri of arsenic treated and untreated rats. Uterus from untreated rats showed presence of ER $\alpha$ (Figure 4a) whereas rats exposed to arsenic showed significant downregulation of ER $\alpha$ in the uterine endometrium (Figure $4 \mathrm{~b}$ ). Similar results were observed in the muscle layer of the control (Figure 4c) and the arsenic-treated uterus (Figure 4d). In order to further validate the effect of arsenic on the expression of estrogen receptors in the rat uterus, the expression was monitored both at the RNA transcript levels and at the protein levels. Semi-quantitative RT-PCR confirmed that the level of ER $\alpha$ was downregulated as a result of arsenic treatment as compared to the control uterus (Figure 5a). Western blot analyses further confirmed that concentration of the estrogen receptor protein declined by almost 2 -fold as a result of exposure to arsenic (Figure 5b).

\section{Effect of arsenic on vascular endothelial growth factor}

Since arsenic is a potent environmental estrogen and responsible for downregulation of the estrogen receptor, we investigated the effects of arsenic on the estrogen signaling pathway. Concomitantly, we selected vascular endothelial growth factor (VEGF) as the estrogenresponsive gene, since it is known to respond primarily to estrogen administration in the uterine epithelium and stroma. The expression of VEGF was thus evaluated at the transcriptional and translational levels. Semi-quantitative RT-PCR revealed a 2 -fold reduction of VEGF transcripts and protein in the arsenic-treated rat uterus (Figure 6), indicating that arsenic not only down regulates the estrogen receptor, but also disrupts the downstream gene expression in the rat uterus.

\section{Effect of arsenic on the cell cycle regulatory proteins}

It is well established that decreased levels of estrogen can affect the expression of the cell cycle regulators, especially those that are involved in the G1-S transition, chiefly cyclin D1 and CDK4. Concomitantly, we investigated if arsenic, which decreased the serum estradiol levels and estrogen receptor expression in female rats, would additionally alter the expression of cyclin D1 and CDK4. The results indicated significant reduction in cyclin D1 and CDK4 mRNA levels in uteri of rats exposed to arsenic, as compared to unexposed rats (Figure 7a). Concomitant downregulation in the expression of cyclin D1 and CDK4 proteins was also observed in uteri of rats exposed to arsenic treatment (Figure 7b). 
Table 3: Luminal diameter, height of luminal epithelial cells, diameter of endometrial glands and width of longitudinal muscles in different experimental groups of adult female rats

\begin{tabular}{|c|c|c|c|c|}
\hline Treatment & Luminal diameter $(\mu \mathrm{m})^{\#}$ & $\begin{array}{l}\text { Height of luminal epithelial } \\
\text { cells }(\mu \mathrm{m})^{\S}\end{array}$ & $\begin{array}{l}\text { Diameter of endometrial } \\
\text { glands }(\mu \mathrm{m})^{\S}\end{array}$ & $\begin{array}{l}\text { Width of longitudinal muscle } \\
\text { layer }(\mu \mathrm{m})^{\S}\end{array}$ \\
\hline Control & $45.88 \pm 1.87$ & $18.44 \pm 0.19$ & $58.95 \pm 3.04$ & $75.89 \pm 0.68$ \\
\hline $4 \mu \mathrm{g} / \mathrm{ml} \mathrm{NaAsO}{ }_{2}$ & $10.72 \pm 0.51^{* *}$ & $5.7 \pm .04^{* * *}$ & $16.61 \pm 0.44^{* *}$ & $37.69 \pm 1.6^{* *}$ \\
\hline
\end{tabular}

Histological analysis was carried out for each control and arsenic-treated rat, and the uterine parameters were measured by occulometry. Each value represents mean $\pm S E, n=5$. (ANOVA followed by multiple Students' t-tests, ${ }^{* *} p<0.01$, ${ }^{* *} p<0.001$, as compared with respective controls). "Magnification: 10x; ${ }^{\S}$ magnification: 40×.

\section{Discussion}

In this study we report the effects of inorganic arsenic on the estrogen signaling pathway in rats, along with concomitant alterations of the uterine morphology and proliferation, to unravel the putative mechanisms behind reproductive failures associated with arsenic exposure. Rats were chronically (28 days) exposed to arsenite $(4 \mu \mathrm{g} /$ $\mathrm{ml}$ ) in drinking water in order to establish a correlation between uterine pathology, serum estradiol and gonadotropin concentrations, and alterations in expression of the estrogen receptor and downstream components, involved with uterine tissue architecture and function, following arsenic treatment. It is evident from the results that arsenic exposure diminishes the circulating levels of both gonadotropins and estradiol. This is further supported by the fact that ovarian steroidogenesis involves enzymes regulated by the gonadotropins FSH and LH, both of which have been reported to be inhibited following exposure to arsenic [49]. Consequently, low serum levels of FSH and $\mathrm{LH}$ in arsenic-treated rats lead to reduction in estradiol production and thus secretion into circulation. Some reports have postulated that the decrease in gonadotropin levels may be due to an increase in plasma glucocorticoids in arsenic-treated rats, since increase in ACTH levels is known to suppress gonadotropin secretion [38].

The finding that arsenic exposure did not affect the total body weight during the exposure period, but decreased the uterine wet weight by almost $30 \%$ may be attributed to the fact that the effect of arsenic is very specific to the uterus in the tested time period. This is further supported by the fact that estradiol regulates uterine weight, and thus, low levels of estradiol lead to the specific reduction of uterine wet weight in the exposed animals. In addition, constant diestrus in arsenic-treated rats after $20 \pm 2$ days may also be due to low serum levels of estradiol [50-52].

In addition to altering the uterine wet weight, arsenic also leads to tissue degeneration in the uterus. The degenerative changes may be attributed to adverse effects caused by decreased serum estradiol levels, since uterine growth is primarily dependant on estradiol. The insufficient concentration of estradiol failed to maintain the normal uterine architecture and led to degeneration of the luminal epithelial cells and endometrial glands. Arsenic is known to generate reactive oxygen species and leads to oxidative damage to several components of the cell, including denaturation of proteins critical to cell functions [53-58]. Thus, degeneration of the uterine endometrial components may be associated not only with downregulated serum estradiol levels but also with increased production of reactive oxygen species following exposure to arsenic [56].

Arsenic is known to act as a potent environmental estrogen [32]. Subsequently, it was hypothesized that arsenic may mimic an estrogenic mechanism to induce lesions in the rat uterus, disrupt the estrogen signaling pathway and consequently lead to reproductive failures. Accordingly, the effect of arsenic on the expression of estrogen receptor, the estrogen responsive gene VEGF, and cell cycle regulatory proteins like CDK4 and cyclin D1 was investigated in the rat uterus. It is known that the estrogen receptor is a hormone-activated transcription factor which mediates the biological effects of estrogen in the target tissue by stimulating the expression of estrogen-regulated genes. The sensitivity of a given tissue to estrogen thus varies with the level of estrogen receptors present in it [59]. Our studies have revealed that arsenic treatment significantly downregulated the expression of $\mathrm{ER} \alpha$ and its downstream element VEGF in the uterus, indicating that arsenic either suppresses the bonafide action of estradiol on the uterus by decreasing the expression of specific receptors, at both the mRNA transcript and protein levels, or acts via a parallel mechanism in the rat uterus that eventually disrupts the estrogen signaling pathway and the G1 cell cycle proteins responsible for cell proliferation. Estradiol-regulated VEGF is chiefly responsible for modulating in vivo angiogenesis in the uterus, and its downregulation by arsenic may be a primary cause for spontaneous abortions, still-births and other reproductive failures. The D-type cyclins are known to be ratelimiting for the progression through the G1 phase of the 

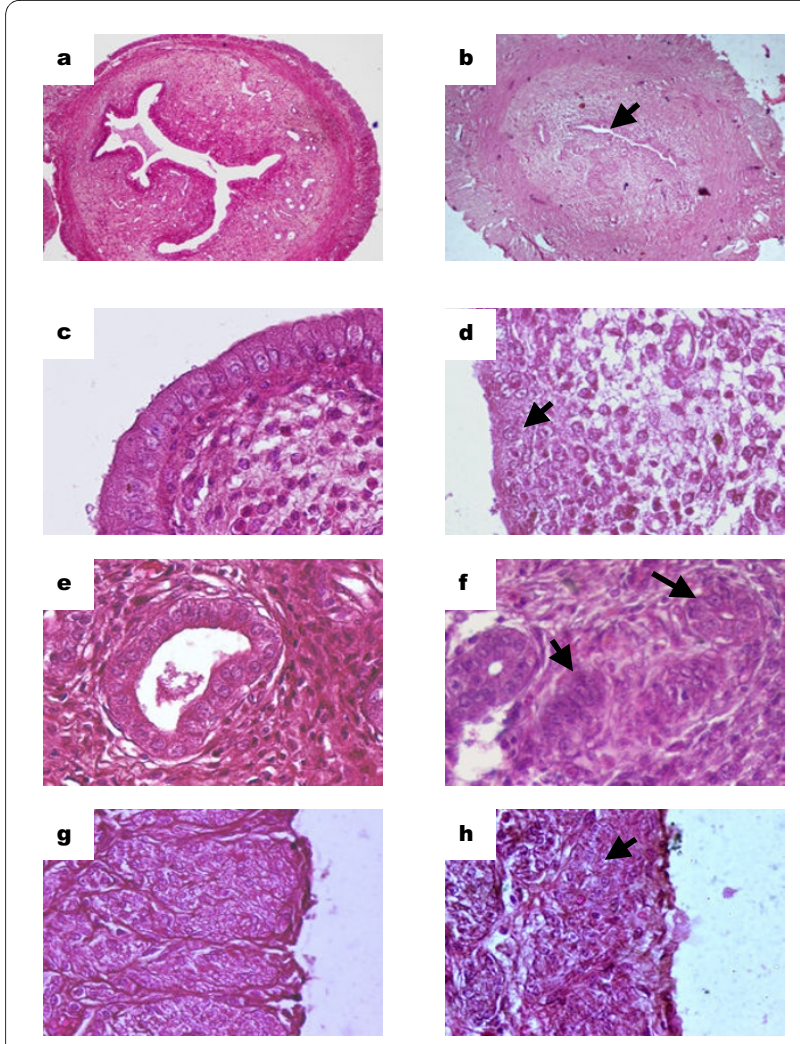

Figure 3 Alterations in tissue architecture of arsenic-treated rat uterus. Rats were treated with or without $4 \mu \mathrm{g} / \mathrm{ml}$ arsenic for 28 days. $3 \mathrm{a}, 3 \mathrm{c}$, 3e and 3g: control sections; 3b, 3d, 3f and 3h: arsenic-treated sections. Uterine sections were subjected to double staining with hematoxylin and eosin and examined under the microscope. (3a, 3b) A significant decrease in width and invaginations of the arsenic-treated uterine lumen was observed in the treated sections (10x magnification) as compared to untreated one. (3c, 3d) Reduction in the height of luminal epithelial cells (as measured by occulometry) in the arsenictreated sections was observed as compared to untreated one (40X). In addition, degeneration of the layer was also noted in the treated uterus. $(3 e, 3 f)$ Arsenic treatment resulted in a significant reduction in the size of endometrial glands, with disappearance of the lumen and disorganization of the epithelial cells lining the glands. $(3 \mathrm{~g}, 3 \mathrm{~h}) \mathrm{As}$ compared to the control uterus, significant reduction in size and organization of the longitudinal muscle layer was observed in the arsenic-treated uterine sections.

cell cycle [60]. In fact, a strong correlation between the expression of increased levels of cyclin D1 mRNA and ER over-expression has been reported [61]. In addition, estrogens are known to increase cell proliferation by recruiting resting cells into the cell cycle, reducing the length of $\mathrm{G1}$ phase and promoting entry of cells to the $\mathrm{S}$ phase [62]. Arsenic, on the other hand, decreased the expression of uterine estrogen receptors, and consequently suppressed cell cycle progression and reduced

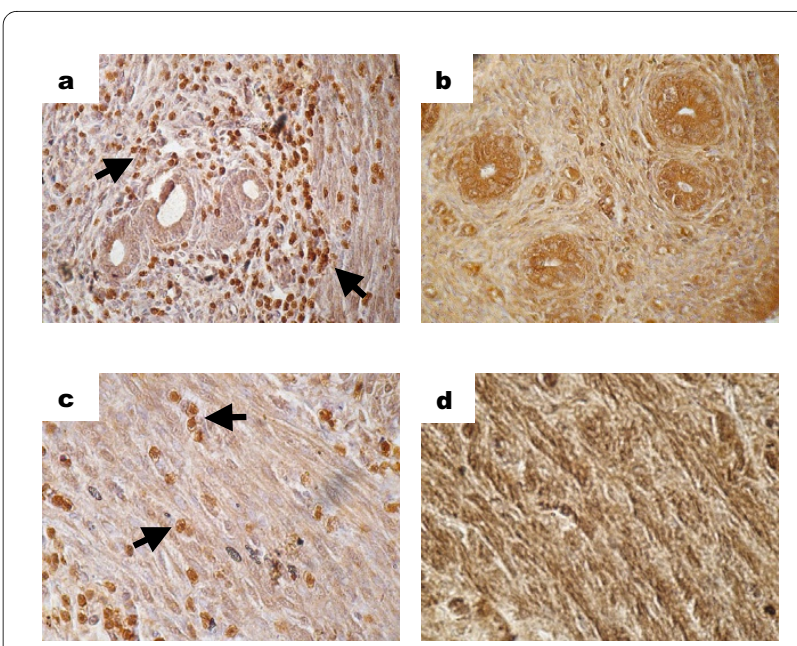

Figure $\mathbf{4}$ Immunohistochemical localization of estrogen receptor in the rat uterine sections. Rats were treated with arsenic for 28 days and tissues were stained for the presence of the estrogen receptor. Arsenic significantly downregulated the estrogen receptors in the endometrial stroma (4b) as compared to the untreated uterus (4a). In addition, the expression of estrogen receptors was also decreased in the longitudinal muscle layer (4d) in contrast to the expression in the muscle layer of the control uterus (4c).

the proliferation-promoting effects of estradiol in the rat uterus.

\section{Conclusions}

It may thus be concluded that sodium arsenite is a nonsteroidal environmental estrogen that is responsible for reducing the serum levels of gonadotropins and estradiol, which in turn lead to uterine tissue degeneration and disruption of the estrogen signaling pathway. The effects of arsenic on the uterus may occur by reducing the expression of estrogen receptors and estrogen responsive genes, and/or by generating reactive oxygen species that lead to oxidative damage of the proteins involved in the estrogen signaling pathway, that regulate the uterine structure and function. Interestingly, liver toxicity assays carried out in our laboratory did not indicate significant differences in the SGPT or SGOT levels in the experimental animals as compared to the control ones (data not shown). Hence, it may be imperative to state that level of arsenic which failed to reduce general body weight of the rats or even affect the liver toxicity enzymes, were capable of bringing about such severe detrimental changes in the uterine physiology and steroid signaling pathway. Finally, our study demonstrates that arsenic at low but chronic doses, relevant to the exposure level in different parts of the world, is a major endocrine disruptor and thus, may be 


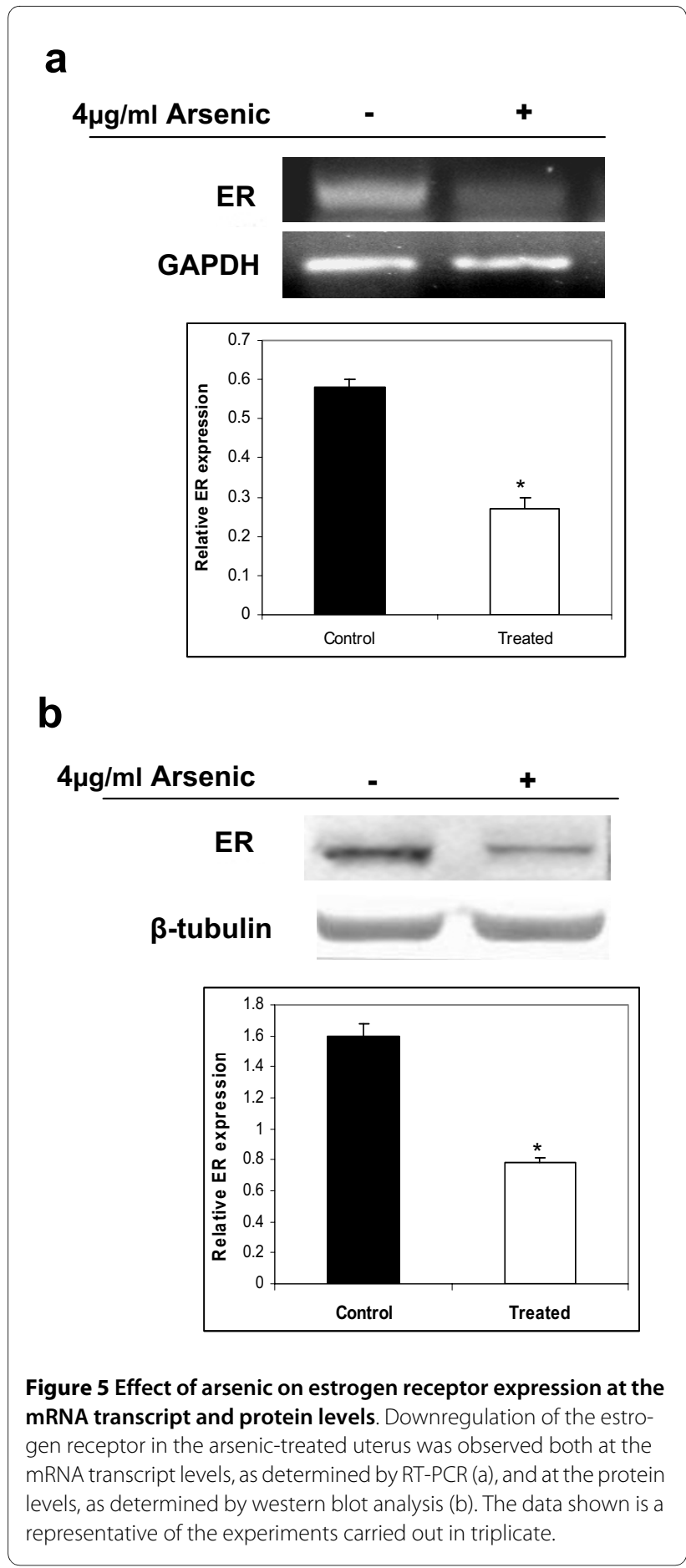

responsible for the different reproductive failures seen in women exposed to such levels of arsenic.

\section{List of abbreviations}

DEPC: Diethyl Pyro Carbonate; EDTA: Ethylene Diamine Tetra Acetic Acid; FSH: Follicle Stimulating Hormone; GAPDH: Glyceraldehyde 3-Phosphate Dehydrogenase; a
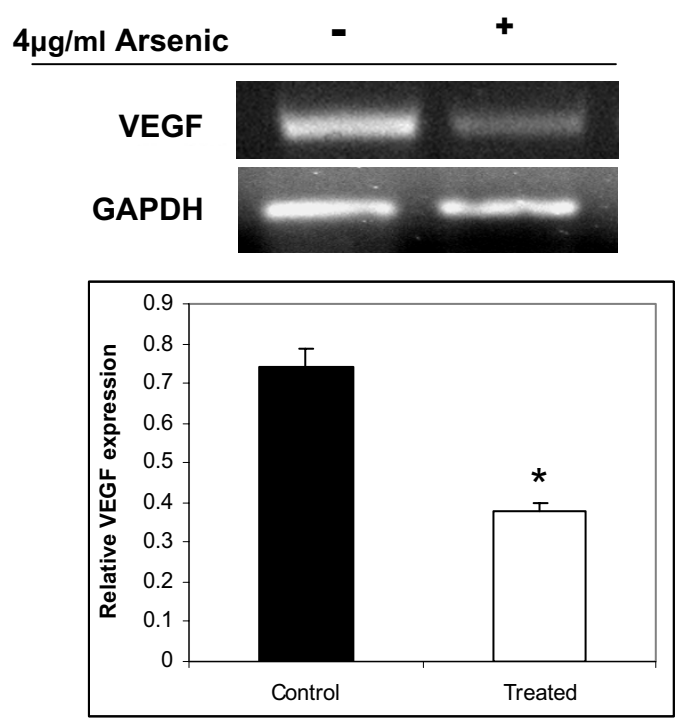

b
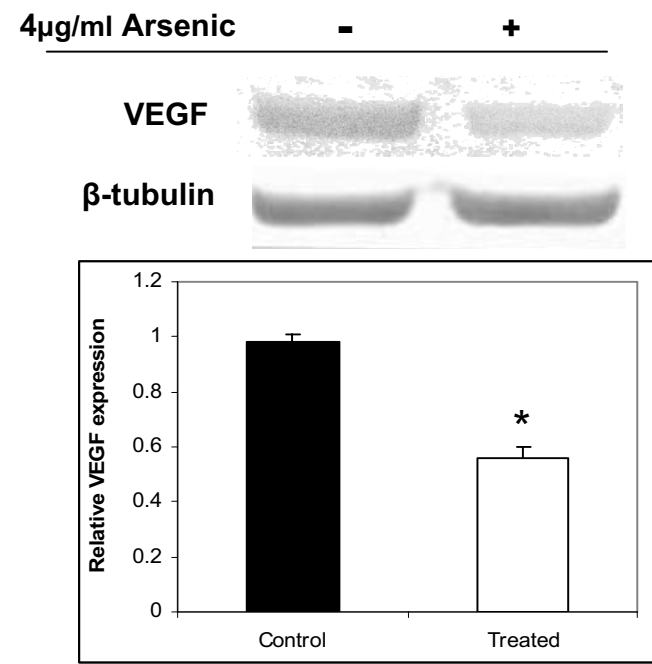

Figure 6 Arsenic downregulated VEGF expression in the rat uterus. Expression of VEGF, an estrogen-responsive gene, was observed to be downregulated both at the transcriptional (a) and translational levels (b), as determined by semi-quantitative RT-PCR and western blot analysis, respectively, in the uterus of arsenic-treated rats. The data shown is a representative of three independent experiments.

HRP: Horse Radish Peroxidase; LH: Luteinizing Hormone; MuLV: Murine Leukemia Virus; NADPH: Nicotinamide Adenine Diphosphate Nucleotide; PBS: Phosphate Buffered Saline; PBST: Phosphate Buffer Saline Tween20; RH: Relative Humidity; RIPA: Radio Immuno Precipitation Assay; RT-PCR: Reverse Transcriptase Polymerase Chain Reaction; VEGF: Vascular Endothelial Growth Factor 


\section{a}

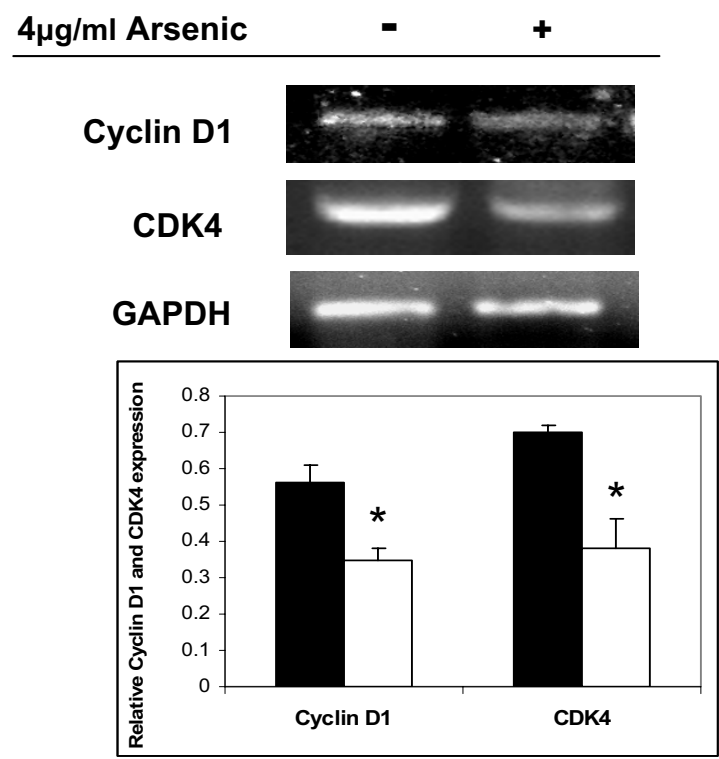

b

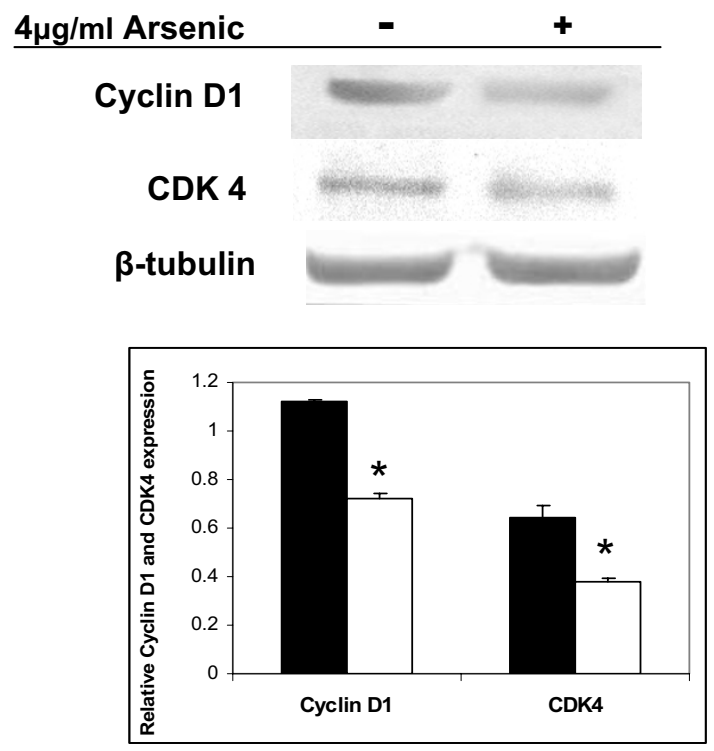

Figure 7 Regulation of G1 cell cycle proteins by arsenic in rats. Female rats were treated with arsenic at a dose of $4 \mu \mathrm{g} / \mathrm{ml}$ for 28 days. Cyclin D1 and CDK4 expressions were analyzed both at the mRNA levels (a) and protein levels (b), using GAPDH and $\beta$-tubulin as loading controls, respectively. It was observed that arsenic downregulated both cyclin D1 and CDK4 (white bars) in the uterus of Sprague-Dawley rats, as compared to the control animals (black bars). The data shown is a representative of the experiments carried out in triplicate.

Competing interests

The authors declare that they have no competing interests.

\section{Authors' contributions}

AC carried out the treatment of animals and performed all the experiments. UC conceived the study, participated in its design, coordination, interpretation and analysis of the data. AC and UC drafted the manuscript. All authors read and approved the final manuscript.

\section{Authors' information}

U.C. - Ph.D., Associate Professor, Department of Zoology, University of Calcutta A.C. - M.Sc., Senior Research Fellow, Department of Zoology, University of Calcutta

\section{Acknowledgements}

The authors are grateful to the University Grants Commission, New Delhi, India, for providing the financial support to U.C. [F. No. 31-227/2005 (SR)] and the RFSMS, University Grants Commission, New Delhi, India, for providing the research fellowship to A.C. We also acknowledge the Department of Science and Technology, New Delhi, for providing the infrastructure support (FIST) to the department.

\section{Author Details}

Department of Zoology, University of Calcutta, 35 Ballygunge Circular Road, Kolkata-700019, India

Received: 7 May 2010 Accepted: 2 July 2010

Published: 2 July 2010

\section{References}

1. Klein CB, Leszczynska J, Hickey C, Rossman TG: Further evidence against a direct genotoxic mode of action for arsenic-induced cancer. Toxicol Appl Pharmacol 2007, 222(3):289-297.

2. Erbanova L, Novak M, Fottova D, Dousova B: Export of arsenic from forested catchments under easing atmospheric pollution. Environ $\mathrm{SCi}$ Technol 2008, 42(19):7187-7192.

3. Abernathy CO, Thomas DJ, Calderon RL: Health effects and risk assessment of arsenic. J Nutr 2003, 133(5):1536S-1538S.

4. Smith AH, Hopenhayn-Rich C, Bates MN, Goeden HM, Hertz-Piccioto I, Duggan HM, Wood R, Kosnett MJ, Smith MT: Cancer risks from arsenic in drinking water. Environ Health Perspect 1992, 97:259-267.

5. Tapio S, Grosche B: Arsenic in the aetiology of cancer. Mutat Res 2006, 612(3):215-246.

6. Watanabe C, Inaoka T, Matsui T, Ishigaki K, Murayama N, Ohtsuka R: Effects of arsenic on younger generations. J Environ Sci Health A Tox Hazard Subst Environ Eng 2003, 38(1):129-139.

7. Suk WA, Ruchirawat KM, Balakrishnan K, Berger M, Carpenter D, Damstra T, de Garbino JP, Koh D, Landrigan PJ, Makalinao I, Sly PD, Xu Y, Zheng BS: Environmental threats to health in Southeast Asia and the Western Pacific. Environ Health Perspect 2003, 111(10):1340-1347.

8. Chiou HY, Chiou ST, Hsu YH, Chou YL, Tseng CH, Wei ML, Chen CJ: Incidence of transitional cell carcinoma and arsenic in drinking water: a follow up study of 8102 residents in an arseniasis-endemic area in northeastern Taiwan. Am J Epidemiol 2001, 153(5):411-418.

9. Walker M, Fosbury D: Arsenic, As (III), and tungsten in Nevada County's private water supplies. J Water Health 2009, 7(2):293-301.

10. Cai L, Liu G, Rensing C, Wang G: Genes involved in arsenic transformation and resistance associated with different levels of arsenic-contaminated soils. BMC Microbiol 2009:1-11.

11. Steinmaus C, Moore L, Hopenhayn Rich C, Biggs ML, Smith AH: Arsenic in drinking water and bladder. Cancer Invest 2000, 18(2):174-182.

12. Karagas MR, Stukel TA, Morris JS, Tosteson TD, Weiss JE, Spencer SK, Greenberg ER: Skin cancer risk in relation to toenail arsenic concentration in an US population based case-control study. Am J Epidemiol 2001, 153(6):559-565.

13. Liu J, Waalkes MP: Liver is a target of arsenic carcinogenesis. Toxicol Sci 2008, 105(1):24-32.

14. Navas-Acien A, Silbergeld EK, Streeter RA, Clark JM, Burke TA, Guallar E: Arsenic exposure and type 2 diabetes: a systematic review of the experimental and epidemiologic evidence. Environ Health Perspect 2006, 114(5):641-648.

15. Prozialeck WC, Edwards JR, Nebert DW, Woods JM, Barchowsky A, Atchison WD: The vascular system as a target of metal toxicity. Toxicol Sci 2008, 102(2):207-218. 
16. Bodwell JE, Gosse JA, Nomikos AP, Hamilton JW: Arsenic disruption of steroid receptor gene activation: complex dose-response effects are shared by several steroid receptors. Chem Res Toxicol 2006, 19(12):1619-1629.

17. Karagas MR, Stukel TA, Tosteson TD: Assesment of cancer risk and environmental levels of arsenic in New Hampshire. Int J Hyg Environ Health 2002, 205(1):85-94

18. Chakraborti D, Rahman MM, Paul K, Chowdhury UK, Sengupta MK, Lodh D, Chanda CR, Saha KC, Mukherjee SC: Arsenic calamity in the Indian subcontinent what lessons have been learned? Talanta 2002, 58(1):3-22.

19. Arsenic health topic: [http://www.who.int/topics/arsenic/en/].

20. Kristoforovic-llic MJ, Bjelanovic JM, Ilic MP, Vidovic MM: Arsenic contamination in environment in the region of Vojvodina. Cent Eur J Public Health 2009, 17(3):152-157.

21. Utsunomiya S, Peters SC, Blum JD, Ewing RC: Nanoscale mineralogy of arsenic in a region of New Hampshire with elevated as-concentrations in the ground water. Am Mineralogist 2003, 88(11-12):1844-1852.

22. Smith E, Smith J, Smith L, Biswas T, Correll R, Naidu R: Arsenic in Australian environment: an overview. J Environ Sci Health A Tox Hazard Subst Environ Eng 2003, 38(1):223-239.

23. Guo X, Fujino Y, Kaneko S, Wu K, Xia Y, Yoshimura T: Arsenic contamination of groundwater and prevalence of arsenical dermatosis in the Hetao plain area, Inner Mongolia, China. Mol Cell Biochem 2001, 222(1-2):137-140.

24. Groundwater arsenic contamination in West Bengal-India (20 years study): [http://www.soesju.org/arsenic/wb.htm]

25. Cui X, Li S, Shraim A, Kobayashi Y, Hayakawa T, Kanno S, Yamamoto M, Hirano S: Subchronic exposure to arsenic through drinking water alters expression of cancer related genes in rat liver. Toxicol Pathol 2004, 32(1):64-72.

26. Myers SL, Lobdell DT, Liu Z, Xia Y, Ren H, Li Y, Kwok RK, Mumford JL, Mendola P: Maternal drinking water arsenic exposure and perinatal outcomes in inner Mongolia, China. J Epidemiol Commun Health 2009, 64(4):325-329

27. Waalkes MP, Liu J, Chen H, Xie Y, Achanzar WE, Zhou YS, Cheng ML, Diwan BA: Estrogen signaling in livers of male mice with hepatocellular carcinoma induced by exposure to arsenic in utero. J Nat Cancer Inst 2004, 96(6):466-474

28. Shen J, Liu J, Xie Y, Diwan BA, Waalkes MP: Fetal onset of aberrant gene expression relevant to pulmonary carcinogenesis in lung adenocarcinoma development induced by in utero arsenic exposure. Toxicol Sci 2007, 95(2):313-320.

29. Goering PL, Aposhian HV, Mass MJ, Cebrian M, Beck BD, Waalkes MP: The enigma of arsenic carcinogenesis: role of metabolism. Toxicol Sci 1999 49(1):5-14.

30. Barret JR: NTP multigenerational study of environmental estrogens. Environ Health Perspect 2006, 114(6):A348-349.

31. Davey JC, Bodwell JE, Gosse JA, Hamilton JW: Arsenic as an endocrine disruptor: effects of arsenic on estrogen receptor-mediated gene expression in vivo and in cell culture. Toxicol Sci 2007, 98(1):75-86.

32. Stoica A, Pentecost E, Martin MB: Effects of arsenite on estrogen receptor-á expression and activity in MCF-7 breast cancer cells. Endocrinol 2000, 114:3595-3602.

33. Hyder SM, Chiappetta C, Stancel GM: Synthetic estrogen 17a ethinyl estradiol induces pattern of uterine gene expression similar to endogenous estrogen $17 \beta$ estradiol. J Pharmacol ExpTher 1999 290(2):740-747

34. Gargett CE, Zaitseva M, Bucak K, Chu S, Fuller PJ, Rogers PA: 17 estradiol up-regulates vascular endothelial growth factor receptor-2 expression in human myometrial microvascular endothelial cells: role of estrogen receptor $\alpha$ and $\beta$. J Clin Endocrino/ Metab 2002, 87(9):4341-4349.

35. Bryant W, Snowhite AE, Rice LW, Shupnik MA: The estrogen receptor (ER) a variant delta 5 exhibits dominant positive activity on ER-regulated promoters in endometrial carcinoma cells. Endocrinol 2005 146(2):751-759

36. Bashir S, Sharma Y, Irshad M, Nag TC, Tiwari M, Kabra M, Dogra TD: Arsenic induced apoptosis in rat liver following repeated 60 days exposure. Toxicol 2006, 217(1):63-70.
37. Waalkes MP, Ward JM, Liu J, Powell DA, Diwan BA: Urogenital carcinogenesis in female CD1 mice induced by in utero arsenic exposure is exacerbated by postnatal diethylstilbestrol treatment. Cancer Res 2006, 66(3):1337-1345.

38. Jana K, Jana S, Samanta PK: Effects of chronic exposure to sodium arsenite on hypothalamo-pituitary-testicular activities in adult rats: possible an estrogenic mode of action. Rep Biol Endocrinol 2006, 4:1-13.

39. Ratcliff WA, Carter GD, Dowsett M, Hillier SG, Middle JG, Reed MJ: Oestradiol essays: applications and guidelines for the provision of clinical biochemistry service. Ann Clin Biochem 1988, 25:466-483.

40. Ofusori DA, Caxton-Martins EA, Komolafe OO, Oluyemi KA, Adeeyo OA, Ajayi SA, Oluwayinka PO, Adelakun EA, Keji ST, Adesanya OA: A comparative study of the ileum in rat (Rattus norvegicus), bat (Eidolon helvum) and pangolin (Manis tricuspis) as investigated using histological method. Int J Morpho/ 2008, 26(1):137-141.

41. Bodine PV, Green J, Harris HA, Bhat RA, Stein GS, Lian JB, Komm BS: Functional properties of a conditionally phenotypic, estrogen responsive, human osteoblast cell Line. J Biol Chem 1997, 65(3):368-387.

42. Bodine PV, Henderson RA, Green J, Aronow M, Owen T, Stein GS, Lian JB, Komm BS: Estrogen receptor-a Is developmentally regulated during osteoblast differentiation and contributes to selective responsiveness of gene expression. Endocrino/ 1998, 139(4):2048-2057.

43. Sugihara T, Wadhwa R, Kaul SC, Mitsui Y: A novel alternatively spliced form of murine vascular endothelial growth factor, VEGF 115. J BiO Chem 1998, 273(5):3033-3038.

44. Corroyer S, Maitre B, Cazals V, Clement A: Altered regulation of $G_{1}$ cyclins in oxidant-induced growth arrest of lung alveolar epithelial cells. Accumulation of inactive cyclin E-DCK2 complexes. J Biol Chem 1996, 271(41):25117-25125.

45. Kowalski AA, Graddy LG, Vale-Cruz DS, Choi I, Katzenellenbogen BS, Simmen FA, Simmen RC: Molecular cloning of porcine estrogen receptor- $\beta$ complementary DNAs and developmental expression in periimplantation embryos. Biol Reprod 2002, 66(3):760-769.

46. Chatterji U, Riby JE, Taniguchi T, Bjeldanes EL, Bjeldanes LF, Firestone GL: Indole 3-carbinol stimulates transcription of the interferon gamma receptor 1 gene and augments interferon responsiveness in human breast cancer cells. Carcinogen 2004, 25(7):1119-1128.

47. Cohen J, Cohen P, West SG, Aiken LS: Applied multiple regression/ correlation analysis for the behavioral sciences. Mahawai, NJ: Lawrence Earbaum Association Press; 2003

48. Ferguson GA, Takane Y: Statistical analysis in psychology and education. Montreal: McGraw Hill Press; 2005.

49. Sarkar M, Biswas NM, Ghosh D: Effect of sodium arsenite on testicular $\Delta^{5}$ $3 \beta, 17 \beta-H S D$ activities in albino rats: dose and duration dependent responses. Med Sci Res 1991, 19:789-790.

50. Chattopadhyay S, Ghosh S, Debnath J, Ghosh D: Protection of sodium arsenite-induced ovarian toxicity by coadministration of L-Ascorbate (Vitamin C) in mature Wistar strain rat. Arch Environ Contam Toxicol 2001, 41(1):83-89.

51. Chattopadhyay S, Pal Ghosh S, Ghosh D, Debnath J: Effect of dietary coadministration of sodium selenite on sodium arsenite- induced ovarian and uterine disorders in mature albino rats. Toxicol Sci 2003, 75(2):412-422.

52. Sasson R, Dantes A, Tajima K, Amsterdam A: Novel genes modulated by FSH in normal and immortalized FSH-responsive cells: new insights into the mechanism of FSH action. FASEB J 2003, 17(10):1256-1266

53. Akram Z, Jalali S, Shami SA, Ahmad L, Batool S, Kalsoom O: Adverse effects of arsenic exposure on uterine function and structure in female rat. Exp Toxicol Pathol 2009, 62(4):451-459.

54. Kitchin KT: Recent advances in arsenic carcinogenesis: modes of action, animal model systems and methylated arsenic metabolites. Toxicol Appl Pharmacol 2001, 172(3):249-261.

55. Liu SX, Davidson MM, Tang X, Walker WF, Athar M, Ivanov V, Hei TK: Mitochondrial damage mediates genotoxicity of arsenic in mammalian cells. Cancer Res 2005, 65(8):3236-3242.

56. Colognato R, Coppede F, Ponti J, Sabbioni E, Migliore L: Genotoxicity induced by arsenic compounds in peripheral human lymphocytes analysed by cytokinesis-block micronucleus assay. Mutagen 2007 22(4):255-261. 
57. Salnikow K, Zhitkovich A: Genetic and epigenetic mechanisms in metal carcinogenesis and cocarcinogenesis: nickel, arsenic and chromium. Chem Res Toxicol 2008, 21(1):28-44.

58. Liu J, Chen H, Miller DS, Saavedra JE, Keefer LK, Johnson DR, Klaassen CD, Waalkes MP: Overexpression of glutathione $S$-transferase II and multidrug resistance transport proteins is associated with acquired tolerance to inorganic arsenic. Mol Pharmacol 2001, 60(2):302-309.

59. Waalkes MP, Keefer LK, Diwan BA: Induction of proliferative lesions of the uterus, testes, and liver in swiss mice given repeated injections of sodium arsenate: possible estrogenic mode of action. Toxicol Appl Pharmacol 2000, 166(1):24-35.

60. Waalkes MP, Liu J, Diwan BA: Transplacental arsenic carcinogenesis in mice. Toxicol Appl Pharmacol 2007, 222(3):271-280.

61. Dickson RB, Stancel GM: Estrogen receptor- mediated processes in normal and cancer Cells. J Natl Cancer Inst Monogr 2000, 27:135-145.

62. Clarke R, Leonessa F, Welch JN, Skaar TC: Cellular and molecular pharmacology of antiestrogen action and resistance. Pharmacol Rev 2001, 53(1):25-71.

doi: $10.1186 / 1477-7827-8-80$

Cite this article as: Chatterjee and Chatterii, Arsenic abrogates the estrogensignaling pathway in the rat uterus Reproductive Biology and Endocrinology 2010, 8:80

Submit your next manuscript to BioMed Centra and take full advantage of:

- Convenient online submission

- Thorough peer review

- No space constraints or color figure charges

- Immediate publication on acceptance

- Inclusion in PubMed, CAS, Scopus and Google Scholar

- Research which is freely available for redistribution 